\title{
The Creation of Karimunjawa Song as Tourism Promotion in Hyper-Reality Era
}

\author{
Alan Wijanarko*, Ayu Niza Machfauzia \\ Master of Arts Education, Yogyakarta State University, Yogyakarta, Indonesia \\ *Corresponding author. Email: alanwijanarko@gmail.com
}

\begin{abstract}
Karimunjawa, a tourist destination located in the Java Sea, is now having a lack of good promotion. Songs seem to be able to promote the destination effectively. Especially in the current era of hyperreality, attractive songs that are composed according to current trends have a huge impact. To create the Karimunjawa song, this present study employed the R \& D (Research and Development) model with some stages a creative process by Alma Hawkins, namely 1) feeling, 2) imaging, 3) transforming, and 4) forming. The song was validated by experts of composition, material, and language. Several things needed to be addressed in the Karimunjawa song, including the selection of melodies and lyrics. Therefore, the researchers revised the products based on the results of field tests conducted with more participants. Based on the result of the field test, it is concluded that the Karimunjawa song is a good song to promote the tourist destination. Traditional music elements that are collaborated with electronic music are able to attract listeners.
\end{abstract}

\section{Keywords: Song creation, Karimunjawa, folk song, Promotion, Tourism, Hyperreality}

\section{INTRODUCTION}

Karimunjawa is an archipelago with 27 islands located in the Java Sea, north Jepara, Central Java. The islands have abundant coastlines and marine wealth in the form of various species of coral reefs and fish. Marine wealth attracts both domestic and foreign tourists to visit. Thus, the researchers are interested in creating a piece of art to promote Karimunjawa.

The researchers create a song with the Javanese lyric because there has been no folk song telling the story of Karimunjawa. Folk songs always convey meanings and messages for society. The song describes the atmosphere or situation of the local community as well as the local language used in Karimunjawa [1].

Karimunjawa song is used not only for promoting the tourist destination but also for improving the image of folk songs which are rarely made. Folk songs can be one of the learning media that introduce many entities and values from the locals. The process of creating the Karimunjawa song was based on an R\&D research model with stages of a creative process by Alma Hawkins, namely feeling, imaging, transforming, and forming.

As a promotional media, the concept of Karimunjawa song is adjusted to the trend. The collaboration between traditional and modern music is expected to be accepted by more audience segments. Karimunjawa, a commodity of the tourism industry, requires an image promotion, one of which is through the Karimunjawa song. Thus, Karimunjawa song is expected to introduce the tourist destination.

In terms of promotion, especially in today's era of hyperreality, people often perceive what is seen on the screen as a reality that can be trusted and then acted upon. That is the main reasons for the trend of advertising and promotion. Nowadays, the digital platform is mainly used as advertisement and promotion media, thus the process of introducing Karimunjawa through a song is considered easy.

\section{LITERATURE REVIEW}

According to Matondang [2], songs function as a tool to express thoughts and feelings to. Songs are not only effective to remember texts or words, but they can also influence listeners' thoughts and feelings and change their attitudes and behaviors. The process of creating songs requires emotion and concentration. Songs are formed from harmonious musical elements. The first element of songs is melody. According to Prier [3], a melody is a complete sequence of notes that carry meaning. The conditions of notes are that they are unique, have a clear form, contain an expression, and can be sung. The second element of songs is lyrics. According to the Great Dictionary of Indonesian Language [4], a lyric is a verse, each of which consists of four lines that end with the same sound. In addition, a lyric means to read, or in the context of music it means to sing. Thus, lyrics contain sentences that are sung 
rhythmically. Lyrics also contain specific meaning and purposes.

Karimunjawa Islands are potential tourist destinations with a lack of good promotion media and facilities. Whereas the media and facilities may be in the form of many sectors done by many parties. The promotion may be done by the government, local media, and local artists through artworks and cultural products. Therefore, the researchers tried to promote the tourist destination of Karimunjawa.

Jean Baudrillard's hyperreality theory fulfills the intention and concentration in the creation of the Karimunjawa song by researchers. The discourse of relationship among reality, symbols, and society, especially the significance and symbolism of culture and media is involved in building an understanding of images [6]. Music, in this case, song, is a cultural product representing the objects of discourse above because these objects are elements of song-formation in terms of context and meaning. Thus, the process of creating song is focused on the more significant role of achieving the goal of creating an image.

\section{RESEARCH METHOD}

The method used in this research was R \& D. This type of research deliberately and systematically directed to find, formulate, develop, produce, and test the effectiveness of certain products that are new, effective, efficient, productive, and meaningful [5]. To be able to produce certain products, a needs analysis was conducted to test the effectiveness of the product so that it can be useful for the community. The R\&D method used by the researchers was adapted from Borg and Gall's procedure consisting of initial information collection, planning, initial product development, initial trials, product revisions, field trials, and product revisions [7].

The product development steps by Borg and Gall were then categorized into three. The first phase, the creation stage, consists of four creative stages adapted from the method of Alma M. Hawkins [8]. If the Alma Hawkins method is related to stimulation of body movements, in the context of creating musical works, this method is modified for auditive stimulation. The first stage, feeling, relates to the sensations we feel from life events or discoveries that are considered interesting. The second stage, imaging, is the sensing we perceive as an imaginary response and a new imagination. The third stage is the transformation carried out by finding aesthetic qualities that are closely related to delusions that are still abstract to be transformed into ideas. The last stage, formation, is done by developing the ideas of a product or musical work into something complete and ready to be tried.

\section{RESULT AND DISCUSSION}

\subsection{Preparation Stage}

The information obtained by researchers is about the Karimunjawa attractions and specialties which are then used as the basis of creating the lyric of the song. The highlighted aspects are the Javanese words kremunkremun (vague) which mean many islands scattering in the area, the abundance of natural potential, the sea, beaches, and the mountains that are preserved. They present the natural beauty and diversity of flora and fauna which make Karimunjawa a worth visiting destination [9].

The right ideas and concepts represent Karimunjawa through a pentatonic scale as the melody. The lyric is in the Javanese language, and is made of traditional musical instruments, for example, saron, bonang, flute, and kendhang. The chord progressions, rhythms, and the addition of modern musical instruments are needed to present contemporary music and to give a modern taste in order to attract people of all ages. The collaboration of traditional music and Electronic Dance Music (EDM) is the specialty of the Karimunjawa song created.

To create the songs, the researchers make use of some hardware and software, namely Sibelius (for making song notation), Nuendo (for recording vocals, mixing and mastering), Virtual instruments (for making accompaniment compositions in the form of quasimodern and traditional musical instruments, computer, soundcard, microphone condenser, and midi controller

\subsection{Creation Stage}

The researchers created the songs by employing the phases by Alma M. Hawkins below.

\subsubsection{Feeling}

Feeling all the senses that we perceive from life events or interesting discoveries is our authority. Karimunjawa's potential and right rhythm for the song are the main considerations of creating the song. Thus, before creating, the researchers determine the atmosphere and genre to be used, sukat, tempo, speed, and rhythm. All those elements should be in accordance with the song's purpose, which is to promote Karimunjawa tourism. There are traditional elements that are collaborated with elements of modern music to attract the people of this era. The researchers use the most common sukat 4/4 to make it easy listening. An upbeat and cheerful atmosphere can be expressed by selecting a tempo between $110-120 \mathrm{bpm}$. The selection of these elements is expected to be able to represent the Karimunjawa atmosphere and attract listeners' interest. Through the feeling and imaging process of determining these elements, the researchers select the basic motive for the Karimunjawa song rhythm which is shown in Figure 1. 


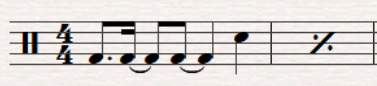

Figure 1. The Rhythm Pattern of Karimun Jawa Song

\subsubsection{Imaging}

The next step after the researchers completing the feeling phase is imaging the lyrics used in the song. What researchers imagine is the outline lyric to be written in the lyric concept.

The lyrics of the Karimunjawa song is in the Javanese language because this song is created as a means of preserving folk songs as national identity and cultural heritage. In composing the lyric, the researchers determine the plot and content of the story for each part of the song by referring to the results of the literature study, observation, and interviews. Then, they write the lyric outline in the Indonesian language before translated into the Javanese language. The process of translation takes a fairly long time as they need to choose the correct words, consider each the number of syllables in one verse, and make each word rhymes. Below is the composed lyric.

Table 1. The lyric of Karimunjawa song

\begin{tabular}{|c|c|c|c|}
\hline $\begin{array}{l}\text { Part of the } \\
\text { Song }\end{array}$ & Content & $\begin{array}{l}\text { Lyric in the Indonesian } \\
\text { Language }\end{array}$ & $\begin{array}{l}\text { Lyric in the Javanese } \\
\text { Language }\end{array}$ \\
\hline \multirow[t]{4}{*}{ Bagian A } & \multirow[t]{4}{*}{$\begin{array}{l}\text { Description of Karimunjawa } \\
\text { attractions }\end{array}$} & $\begin{array}{l}\text { Pemandangan laut yang eksotis } \\
\text { dan pasir putih seperti telaga } \\
\text { warna } \\
\text { Exotic sea views and white sand } \\
\text { look like a lake of colors. }\end{array}$ & $\begin{array}{l}\text { Sesawangan endah samudra } \\
\text { lan pasir putih pindha telaga } \\
\text { warna }\end{array}$ \\
\hline & & $\begin{array}{l}\text { Banyaknya pulau yang tersebar } \\
\text { dan luas sejauh mata memandang } \\
\text { Many islands are scattered } \\
\text { widely. }\end{array}$ & $\begin{array}{lrr}\text { Sakehing } \quad \text { pulau } & \text { ingkang } \\
\text { sumebar } & \text { saha } & \text { jembar } \\
\text { saadohing } & \text { panyawang } & \end{array}$ \\
\hline & & $\begin{array}{l}\text { Jernihnya air memberi keindahan } \\
\text { di dasar laut } \\
\text { Its clear seawater shows the } \\
\text { beauty of the seabed. }\end{array}$ & $\begin{array}{lrr}\text { Weninging } & \text { tirta } & \text { nyuguhake } \\
\text { kaendahan } & \text { ing } & \text { dasaring } \\
\text { samudra } & & \end{array}$ \\
\hline & & $\begin{array}{l}\text { Beraneka ragam tumbuhan dan } \\
\text { hewan langka } \\
\text { There are various rare sea plants } \\
\text { and animals. }\end{array}$ & $\begin{array}{l}\text { Meneka warna tetanduran sato } \\
\text { kewan ingkang isih langka }\end{array}$ \\
\hline \multirow[t]{2}{*}{ Bagian B } & \multirow[t]{2}{*}{$\begin{array}{l}\text { The origin of Karimunjawa, } \\
\text { promotion to visit and how to } \\
\text { preserve the beauty of } \\
\text { Karimunjawa }\end{array}$} & $\begin{array}{l}\text { Kremun - kremun (Samar - } \\
\text { samar) dari Tanah Jawa yang } \\
\text { indah dan mulia } \\
\text { They are all vaguely seen from } \\
\text { Java island. }\end{array}$ & $\begin{array}{l}\text { Kremun - kremun saka tanah } \\
\text { Jawa kang endah lan mulya }\end{array}$ \\
\hline & & $\begin{array}{l}\text { Mari lihat dan lestarikan warisan } \\
\text { dunia } \\
\text { Let's enjoy and preserve the } \\
\text { nation's heritage. }\end{array}$ & $\begin{array}{l}\text { Mangga mirsani saha } \\
\text { mbudidaya warisan ing ndonya }\end{array}$ \\
\hline Bagian $\mathrm{C}$ & $\begin{array}{l}\text { The feeling when visiting } \\
\text { Karimunjawa }\end{array}$ & $\begin{array}{l}\text { Karimunjawa selalu } \\
\text { mengesankan dan menarik hati } \\
\text { Karimunjawa always amazes and } \\
\text { attracts me. }\end{array}$ & $\begin{array}{l}\text { Karimunjawa tansah } \\
\text { nengsemaken lan anuju prana }\end{array}$ \\
\hline
\end{tabular}




\begin{tabular}{|l|l|l|l|}
\hline & $\begin{array}{l}\text { Karimunjawa surganya laut selalu } \\
\text { ingin kembali ke sana } \\
\text { Karimunjawa is the heaven of the } \\
\text { seas where I want to visit. }\end{array}$ & $\begin{array}{r}\text { Kamaimana } \\
\text { samadra tansah kepingin bali } \\
\text { mrana }\end{array}$ \\
\hline
\end{tabular}

\subsubsection{Transforming}

The results of determining the rhythm and lyric are then manifested by pouring out all thoughts into melody in the form of notations. The Karimunjawa song is designed to have 3 song parts, namely Parts A, $\mathrm{B}$ and $\mathrm{C}$. Designing the rhyme and determining the rhythm are the basis of creating a song melody. Below is the process of combining the melody and lyric into a complete song.

\subsubsection{Part A}

The first step in creating a melody is creating a motif. Motif is the smallest element in a melody consisting of two tones and occupying the two most space bars [10]. The motif of this song, which can be seen Figure 2 below, is arranged using a pentatonic scale (pelog) to present a traditional atmosphere. The motif goes through a long feeling and imaging process. To make it easier to find motifs, the researchers use the help of chord progressions that are made simultaneously.

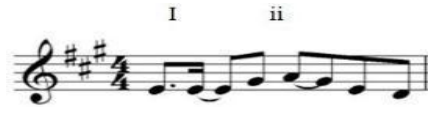

Figure 2. Part A Motif

The next stage after the motive is determined is to develop the motif so that it forms 1 question phrase with 4 bars. Literal repetition or repeating the first motif with slight changes according to the design of the verse and the application of chord progressions are done to develop the motif which is shown in Figure 3 below. The motif results in enthusiastic and cheerful expressions since the selected motif starts on the strong first beat and has a $1 / 16$ note accent.

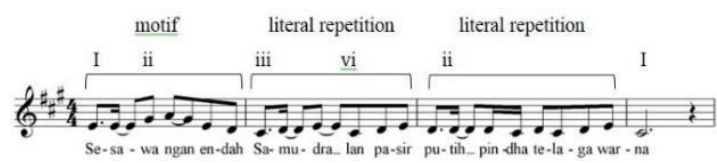

Figure 3. Question phrases part A

The formed question phrase is then developed as an answer phrase by giving a slight change. The last note is raised. Mi is changed into Do (octave) with embat to reflect the tone followed by vibrato as a variation. The combination of verses in the answer phrase is the same as the question phrase which describes the specialty of Karimunjawa. The researchers make repetitions in part A but use different lyrics with the same expression to enrich the content of the song about Karimunjawa's specialty. The verse in the repetition of part A describes the beauty of the marine, as well as the diversity of flora and fauna. The repetition of part A ends with a gut (bounces on the tone followed by vibrato) that functions as a song variation.

\subsubsection{Part B}

In part $\mathrm{B}$, the researchers make a new motif that is developed into song phrases. The motif of part B starts from the hanging bar. The motif is then developed into a 4-bar question phrase using ascending sequences, as is shown in Figure 4. The motifs and their development give off a sweet (dolce) and grand impression according to the verse "kang endah lan mulya" (beautiful and noble). The last note of the question phrase is given a gregel singing style

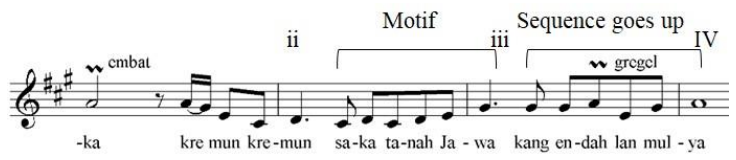

Figure 4. B motif and its development

Then, after completing an answer phrase by repeating the question phrase and giving a little change to the last motif. The end of the answer phrases slows down the beat $1 / 2$ slower than the written note. This answer phrase presents the same impressions as the question phrase, sweet and great.

\subsubsection{Part C}

Part C contains the peak of the song or so-called Chorus. In this section 2, new motifs are created as a chord progression is invented. Motif 1 is filled with the word "Karimunjawa"-the title of the song. Then the tone used is higher than the previous motif to give the impression of a climax. While the second motif is made lower than motif 1 and gregeled in the first tone to give a sweet impression according to the lyrics, namely "tansah nengsemaken" (always being impressive).

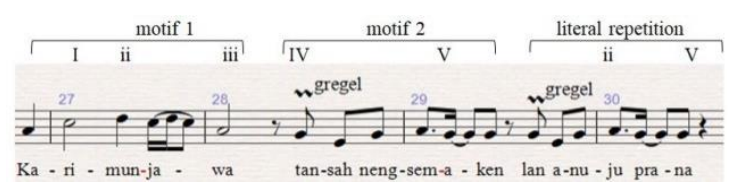

Figure 5. Motif and question phrase in Part C

Motif 2, as is shown in Figure 5 above, is developed by literal repetition at the next bar because it adapts the lyric which has the same expression from the previous one, namely "anuju prana" (interesting). Motifs 1, 2, and literal repetition are combined to form one question phrase. 
The final step is to create an answer phrase by repeating the question phrase and applying a change of quite different pitch to finish the song. Before the last note, the answer phrase is twisted (raising the tone and then lowering it back to the main note). Similar to the question phrase, the first part of the answer phrase is filled with the verse "Karimunjawa" as a climax. Meanwhile, the second motif sounds sweet in accordance with the verse, namely "swargane Samudra" (paradise of the sea). The end of the development of the second motif expresses the longing and desire to return to Karimunjawa. It is presented in the selection of a tone that is higher than the previous notes and an increase in the tone showing an enthusiastic expression and at the end of the song.

\subsubsection{Forming}

The developed melody and lyric are combined with musical aesthetic elements by providing harmony, dynamics, improvisation, and making accompaniment arrangements and recordings. According to Novandhi [11], the arrangement must be visible in the intro, interlude, and coda. Thus, the researchers make a sequence of songs starting from intro - part 1 - part 2 part 3 - interlude - part 2 - part 3 - coda.

The creation process employs music production hardware and software, including the Nuendo application, Plugin instruments (to create accompaniment compositions in the form of quasimodern and traditional musical instruments), computers/laptops, Soundcards, condenser microphones, and MIDI controllers.

To guide the process of making the arrangement, a MIDI controller is used instead of a piano. Then, the drum sound which is initially planned to be made in the feeling step is added to the arrangement. Other instruments, such as bass and strings are added. The researchers add the sound of traditional musical instruments, namely kendhang, saron, and flute in a quasi (imitation of the original) to give a traditional sense. At last, recording the singer's voice is done in the forming stage before the song is ready to be tested.

\subsection{Trial}

\subsubsection{Expert Validation}

This validation involves experts of composition, material, and linguistics. The composition validation is carried out by Dr. Dra. Heni Kusumawati, M.Pd. who is a Lecturer in Composition in the Department of Music Education, Faculty of Languages and Arts, UNY. She said that the process of creating the Karimunjawa song was in accordance with the procedure. Starting from determining the Rhythm, designing lyrics, and creating a melody. The tones and rhythms are of today's musical styles thus making the song accepted easily by the public. However, some melodies end up in tonic, for example, bar 8, 18, and 21. It is better if bar 21 is not a tonic to avoid a monotonous tone, so another tone but still on the IV chord is chosen.

Material validation is carried out by Safigh Pahlevi Lontoh, S.T., a member of the Central Java Regional Tourism Promotion Board. He said that the content of the song represents Karimunjawa tourism area. However, there are several things to consider. The word "Kewan" (animal) used in the lyric is considered impolite. Since there is no other choice for the word "Kewan" in Javanese, it is not changed. Furthermore, in the ending, the tone is too high so that the general listener finds it difficult to imitate, so he recommends that it is changed into the lower one to make it is easier to listen.

Language validation was carried out by Dra. Endang Listiyani, M.Pd., a Javanese language teacher at SMA N 1 Tayu, Pati. She thought that in terms of spelling, dasaring should be changed into dhasaring. Then, the word meneka should be replaced with maneka. In terms of diction, there is a mixed Javaned Krama language with the Ngoko one in the sentence "Sakehing Pulau ingkang Sumebar Saha Jembar". There is a need to choose between whether to use the Krama or Ngoko. Then, there is a suggestion about the pronunciation of the words sakehing, kaendahan, and kremun - kremun.

\subsubsection{Product Revision}

Product revisions are carried out by changing the lyrics and song notation in advance according to the advice of the experts. The basic words in the song lyrics were changed to dhasaring, meneka was replaced with maneka, Ingkang was replaced with Kang to avoid confusing Krama and Ngoko languages. The last note of the song, which was originally $i$ (do), is lowered to 5 (sol) so that it can be sung more easily. However, considering the aesthetic value and structure of the song, the melodies in bars 8,18 , and 21 are not changed. The next step is to change the arrangement by enriching the electronic and traditional instruments. Such as adding electronic drum patterns, original drums, synthetizer melodies, and original flute melodies. Then re-record the vowels with the correct pronunciation, especially for sakehing, kaendahan, and kremun - kremun. The final step is the process of editing, mixing and mastering so that it is ready to be continued at the field test stage

\subsubsection{Field Testing}

The field test stage was carried out by uploading the Karimunjawa song in the form of a lyric video to Youtube so it could reach a wider range of audience. In the video description section, a questionnaire is provided for listeners which aims to evaluate the song. There are 33 respondents who gave an evaluation to the Karimunjawa song. Based on the results of the evaluation, $90.6 \%$ of respondents strongly agree that the Karimunjawa song can be the right means to promote tourism. Respondents also strongly agreed that the song's composition successfully represented Karimunjawa. Respondents also strongly agree that the 
creation of traditional music arrangements that are collaborated with electronic music is appropriate for today's listeners. In addition, song melodies have the potential to attract listeners because they are simple and easy to memorize. There are several suggestions from respondents so that they can be used as reference material for further developments. These suggestions include adding more electronic music elements, giving climax to certain parts of the song, and making video clips at the Karimunjawa location so that the Karimunjawa song will be more effective in promoting tourism.

\section{CONCLUSION}

Based on the research results, it can be concluded that this research and development resulted in a product in the form of the Karimunjawa folk song which will be used as a means of tourism promotion and cultural preservation. The stages taken to create the Karimunjawa song include the preparation, creation stage, and trial. The preparation stage focuses on finding information about Karimunjawa tourism and preparing equipment for song creation. The creation stage consists of four steps, namely: a) feeling, b) imaging, c) transforming, and d) forming. The final result of the creation of the Karimunjawa song is in the form of notation and lyric which is equipped with chord progressions as well as an audio recording used in the trial stage.

In the trial stage, experts of composition, material, and language give suggestions used to revise the song. In terms of composition, the suggestions from experts of material and linguistics are on melody and Javanese lyric. The results of the product revisions then go to a field test. Based on the field test, Karimunjawa song is considered to meet the good creation procedures and is appropriate to be used as a means of tourism promotion. Karimunjawa song can be played at tourism locations along with tourism promotion videos published through social media. Moreover, the song may be played in special events taking place in Central Java or Jepara regency.

\section{REFERENCES}

[1] Pramudita, M. Pembelajaran Lagu Daerah Dalam Menanamkan Apresiasi Siswa Kelas V di SD 3 Blimbing Kidul Kabupaten Kudus [Learning Local Songs in Instilling Appreciation for Class V Students at SD 3 Blimbing Kidul, Kudus Regency] Doctoral dissertation, Universitas Negeri Semarang, 2017.

[2] E. M. Matondang. Pengaruh metode bernyanyi terhadap peningkatan kosakata pada anak TPQ Wardatul Ishlah Joyoraharjo Malang [The effect of the singing method on increasing students' vocabulary in TPQ Wardatul Ishlah Joyoraharjo Malang], unpublished.
[3] Prier, Edmund. Ilmu Bentuk Musik [The Science of Musical Forms], Pusat Musik Liturgi, 2011.

[4] Pusat Bahasa Departemen Pendidikan Nasional, Kamus Besar Bahasa Indonesia [Great Dictionary of Indonesian Language], Balai Pustaka, 2002.

[5] Putra, Nusa, Metode Penelitian Kualitatif Pendidikan [Educational Qualitative Research Methods]. Rajagrafindo Persada, 2013.

[6] Baudrillard, Jean, Simulacra and Simulation, (S. F. Glaser, Trans.), University of Michigan Press, 1994.

[7] Borg, W.R. \& Gall, M.D. Gall, Educational Research: An Introduction, Fifth Edition. Longman, 1983.

[8] Hawkins, A. M, Mencipta Lewat Tari [Creating Through Dance]. Institut Seni Indonesia Yogyakarta, 2003.

[9] Daniar, M. S, Potensi Alam dan Kepariwisataan Kepulauan Karimunjawa Jepara Provinsi Jawa Tengah sebagai Medan Pengembangan Olahraga Rekreasi [The Potential of Nature and Tourism in the Karimunjawa Islands, Jepara, Central Java Province as a Development Field for Recreational Sports]. Doctoral dissertation, Sebelas Maret University, 2016.

[10] Musik, J. P. S., \& Kusumawati, H, Diktat Komposisi [Composition Dictate]. Universitas Negeri Yogyakarta, 2010.

[11] Novandhi, N. K, Implementasi Teori Belajar dalam Mata Kuliah "Arrangement" di S1 Sendratasik Universitas Negeri Surabaya [Implementation of Learning Theory in the Course "Arrangement" at the S1 Sendratasik State University of Surabaya]. Imaji: Jurnal Seni dan Pendidikan Seni, vol. 17, no. 2, 2019, 179-184. 